\title{
An Examination Of The Effectiveness Of CEO Stock Option Granting Decisions Toward R\&D Investments
}

Minna Yu, (E-mail: myu@bsu.edu), Ball State University

\begin{abstract}
Stock options are used to motivate investments in risky projects, such as $R \& D$ investments. When compensation committees make granting decisions to stimulate $R \& D$ spending, they should consider the following firm characteristics: (1) a firm's growth opportunities; (2) a firm's financial leverage; and (3) the CEO's stock ownership prior to stock option grants. This paper addresses the effectiveness of CEO stock option granting decisions by examining whether compensation committees take these three factors into account. Using a recent sample over the period of 1992-2006, we find that firms with greater growth opportunities and firms in lower financial leverage are more likely to award CEO stock options to motivate $R \& D$ investment. These findings are consistent with that options are designed effectively to motivate managerial risk taking, thereby aligning the interests of managers with those of shareholders. However, contrary to our prediction, compensation committees tend to grant more to CEOs with larger stock ownership to induce $R \& D$ spending. A potential explanation for this finding is that CEOs with relatively large stock ownership affect the granting process and grant themselves with excessive stock options. Taken together, the evidence of CEO stock option granting process partially supports the notion that firms make effective stock option plans to mitigate incentive problems of risk-averse managers.
\end{abstract}

Key Words: stock options, CEO stock ownership, R\&D spending

\section{Introduction}

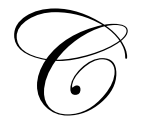

EO stock options granted by U.S. firms rose dramatically in the past two decades. ${ }^{1}$ Theoretically, executive stock options provide incentives for risk-averse managers to invest in risky but value-enhancing projects on behalf of risk-neutral shareholders (e.g., Jensen and Meckling 1976). For example, executive stock options affect managers' decisions of undertaking risky projects (Rajgopal and Shevlin 2002). However, excessive stock options granted to executives relative to firms' modest performance improvement frequently provoke criticism. Prior studies find that the costs of stock options are large (Morgenson 1998; Leonhardt 2000; Meulbroek 2003; Ikaheimo et al. 2004). Furthermore, the managerial incentive to increase stock price is not monotonically increasing in the executive's option wealth (Tian 2004). Due to these concerns with granting stock options, it is not always desirable for firms to maximize stock option grants to motivate CEOs.

This paper is revised from a term paper while being a doctoral student at Kent State University. I am grateful for the suggestions of Pervaiz Alam. I also appreciate comments from William Brown (the discussant) and the participants at the 2004 AAA Northeast Regional Meeting. I am indebted to Peng Cui, Lili Xie, and Gwen White for reviewing this paper for me.

${ }^{1}$ Hall and Murphy (2002) estimate that stock options represent approximately 40\% of CEO's total compensation for S\&P 500 companies in 1998. This is up from only $25 \%$ of total pay in 1992. More recently, the 2001 annual survey of executive pay by the Business Week estimates that options account for $80 \%$ of total CEO pay. 
The purpose of this paper is to empirically investigate the factors companies consider when they grant CEO stock options to motivate risky investments: research and development (R\&D) projects. CEOs are concerned with short-term accounting and stock performance, and these concerns generate incentives for CEOs to reduce R\&D spending (e.g., Cheng 2004). Also, the future benefits of R\&D projects are generally uncertain (e.g., Chan et al. 2001; Kothari et al. 2002). Furthermore, compared with other managerial investments, R\&D projects are relatively difficult to monitor because of the higher information asymmetry between managers and shareholders (e.g., Clinch 1991). Due to these reasons, CEOs tend to cut R\&D spending. Since stock options are a mechanism to mitigate risk-related incentive problems and the value of stock options depends on the market price, compensation committees will use stock options to influence CEOs' incentives to invest in R\&D projects. The focus of this study is on the stock options paid to chief executive officers (CEOs). CEOs have direct control over R\&D investment and granting stock options to them may significantly reduce their reluctance to invest in the risky projects. ${ }^{2}$

Prior studies investigate firm-specific characteristics that provide incentives for firms to grant stock options (e.g., Yermack 1995; Goodwin and Kent 2004). These firm characteristics are: (1) a firm's growth opportunities, (2) a firm's financial leverage, and (3) the CEO's stock ownership prior to stock option grants. When compensation committees make granting decisions to stimulate R\&D spending, they should consider these firm/CEO characteristics. In this paper, we examine whether the above three factors regarding firm/CEO characteristics explain the extent to which compensation committees attempt to use stock options to stimulate R\&D spending. As discussed earlier, stock option grants are a major means for shareholders to stimulate risky investments. Therefore, examining whether the stock option grants are designed appropriately to motivate managerial risk-taking is a suitable approach to address the effectiveness of stock option granting decisions. In addition, we use a sample over the period of 1992-2006, during which the SEC requires the disclosure of stock option granting plans. This disclosing requirement may discipline the compensation committees' work and thus, may enhance the effectiveness of stock options granting.

Using 954 sample firms from the Standard and Poor's 1500 list, we find that the compensation committee more positively links CEO stock option grants with the R\&D investment in order to motivate R\&D spending (1) for a firm facing greater growth opportunities than for a firm facing less growth opportunities, (2) when a firm' financial leverage is relatively low. However, the compensation committee tends to grant more stock options to motivate R\&D spending when the CEO has relatively large stock ownership. One potential explanation is that CEOs with significant stock ownership affect the contracting process and grant themselves with more options.

This paper contributes to both the literature and the industry. This study extends Cheng (2004) by identifying additional factors that influence compensation committees' incentives to motivate R\&D spending. Cheng (2004) documents that compensation committees are more likely to use stock options to motivate R\&D spending when managers may opportunistically reduce R\&D spending (two factors). In this paper, we show that the use of stock options to motivate R\&D spending is also contingent on firm's financing and investment conditions as well as CEO stock ownership.

This study has managerial implications as well by shedding light on how compensation committees attempt to design stock option plans to mitigate incentive problems of managers. We identify three factors that explain compensation committees' attempt of using stock options to encourage R\&D spending. These factors should be considered to implement the CEO stock option plans.

The paper proceeds as follows. Next section reviews related literature. Section 3 develops testable hypotheses. Section 4 presents research methodology. Section 5 discusses sample construct and data sources. Section 6 presents empirical results. In Section 7, we summarize the major findings and conclude.

\footnotetext{
${ }^{2}$ Examining CEO stock options also facilitates the comparisons with prior studies on compensation committees' stock option granting decisions. Furthermore, CEO (as opposed to other executives) compensation is the subject that has received the most intensive debate among various shareholders in the firm (Rajgopal and Shevlin 2002; Murphy 2003).
} 


\section{Literature Review}

\subsection{Effects Of Executive Stock Options}

Despite the pervasive use of executive stock options, there is no consensus of their ex post effects. As summarized by Hanlon et al. (2003), there are two opposing perspectives towards issuing executive (including CEO) stock options: the incentive alignment perspective and the rent extraction perspective. The incentive alignment perspective states that options are granted to reduce the moral hazard problem that stems from senior managers owning very little of the firms they manage. A substantial body of theoretical work beginning with Jensen and Meckling (1976) suggests that stock option contracts can align managers' incentives with those of shareholders. For example, Rajgopal and Shevlin (2002) document that executive stock options affect managers' decisions of undertaking risky but positive net present value projects. Using a sample of oil and gas firms, they investigate exploration risk, the risk of uncertain success in exploring for new oil and gas reserves.

The rent extraction perspective, however, states that senior managers control the pay-setting process and compensate themselves in excess of the level optimal for shareholders. Researchers with this perspective find that stock options are an inefficient way to compensate managers (e.g., Jenter 2001; Hall and Murphy 2002; Meulbroek 2003).

In addition, excessive stock options granted to executives relative to firms' modest performance improvement frequently provoke criticism. First, the costs of stock options are large. Shareholders and other stakeholders worry about the cost of stock option grants in terms of dilution and the resulting share repurchases needed to stem that dilution (e.g., Morgenson 1998; Leonhardt 2000). Ikaheimo et al. (2004) study a sample of Finnish firms and find that the dilution effect has a negative impact on stock returns. The deadweight cost associated with executive stock options is also quite large (Meulbroek 2003). Second, the managerial incentive to increase stock price is not monotonically increasing in the executive's stock option wealth (Tian 2004).

\subsection{Compensation Committee Granting Considerations}

Prior studies document that compensation committees adjust the GAAP earnings specified in incentive plans to shield compensation from income-decreasing effects of restructuring charges (Dechow et al. 1994), extraordinary losses (Gaver and Gaver 1998), strategic expenditures (Duru et al. 2002) as well as income-increasing effects of SFAS No. 106 (Kren and Leauby 1997). Making adjustments in these situations reveals the considerations of compensation committees in CEO cash compensation.

Given that stock option is becoming a dominant component of CEO compensation package since 1990's, examining the practice in stock option granting becomes increasingly interesting and important. In general, it is the compensation committee's responsibility to make appropriate stock option plans. The negative effects of stock options raise doubts about the effectiveness of stock option granting process. If stock option grants are properly constructed, they can be highly effective in aligning CEOs incentives with those of shareholders (Greenspan 2002). Conversely, if the stock options are not awarded properly, then the stock options would not function effectively in motivating the managers' incentives.

Cheng (2004) shows that compensation committees effectively mitigate opportunistic reductions in R\&D expenditures by positively linking stock option adjustments with $R \& D$ spending. It provides supporting evidence on the effectiveness of stock options grants in motivating risky investment. In this study, we argue that compensation committees should consider more firm characteristics when they make granting decisions to motivate R\&D spending. Thus, the current study is an extension to Cheng (2004).

Yermack (1995) studies the impact of firm/CEO characteristics on stock options. The author conjectures that incentives provided by stock option awards will be larger in firms with valuable growth opportunities, in firms with lower financial leverage, and when CEOs hold a small fraction of their own firms' equity. He then uses pay-performance sensitivity to measure the incentives generated by stock options and regresses pay-performance 
sensitivity of stock options on the three firm characteristics. He finds no support for his arguments. The possible reason is that he uses an incomplete measure of stock option incentives. His measure is subject to at least two limitations. First, as realized by Yermack (1995), his measure focuses on the incentives provided by new awards without considering those incentives provided by stock options granted in prior years. He was not able to construct reliable estimates of the incentives from CEOs' accumulated stock option awards due to data constraints. Second, pay-performance sensitivity is a biased measure of managerial incentives and it systematically overstates the incentives generated by stock options (Jenter 2001).

Using Australian firms as their sample, Goodwin and Kent (2004) investigate the firm specific characteristics that provide ex ante incentives for firms to utilize an executive stock option plan. They find that a firm is more likely to utilize a stock option plan as the firm faces more investment opportunities. They also find a positive relationship between the level of remuneration received by the CEO and the existence of an ESO plan. But they do not find a relation between a firm's level of debt and its use of an executive stock option plan. Goodwin and Kent (2004) focus on the issue of whether firms use a stock option plan is contingent on certain firm/CEO characteristics, such as CEO remuneration, investment opportunities, and financial leverage. In the current study, we extend their study by examining how the same three firm characteristics affect the extent to which firms use stock options to stimulate R\&D spending.

\section{Hypotheses Development}

\subsection{R\&D And Stock Option Compensation}

Boards of directors determine stock options granted to CEOs, or they delegate powers to compensation committees to fix or approve the compensation of executives. ${ }^{3}$ They meet multiple times a year to vote and determine compensation schemes. Compensation committees have a significant amount of discretion in deciding on the magnitude of CEO stock options and their decisions are subjective relative to the decisions on cash compensation.

In this paper, we focus on the use of stock options to induce risk taking in $R \& D$ projects. Compensation committees attempt to make a positive connection between stock option grants and $R \& D$ spending to reward or motivate risk taking. The reasons are as follows. First, compensation committees believe that there is a tendency for risk-averse CEOs to cut $\mathrm{R} \& \mathrm{D}$ spending. $\mathrm{R} \& \mathrm{D}$ projects are generally associated with greater certainty of the future benefits (e.g., Chan et al. 2001; Kothari et al. 2002). In addition, the negative impact of R\&D spending on current accounting earning is due to the fact that $\mathrm{R} \& \mathrm{D}$ spending is typically immediately expensed under U.S. GAAP. CEO may also consider R\&D investments as less desirable than other investments in terms of the impact of the investments on short-term stock prices (e.g., Cheng 2004). In sum, CEOs are concerned with short-term accounting and stock performance, and these concerns generate incentives for CEOs to reduce R\&D spending. The second reason for compensation committees to reward $R \& D$ spending using stock options is that, relative to other investments, $R \& D$ projects are often associated with higher information asymmetry between managers and shareholders (e.g., Clinch 1991). In order to align managers' preferences with those of shareholders, compensation should ideally be linked to performance. Because it is hard to monitor the quality of R\&D investment, stock option grants tied to R\&D spending help enhance the chance that only "good" R\&D investments are induced or rewarded (Cheng 2004).

\subsection{Variation In The Relation Between R\&D And CEO Stock Option Compensation}

Despite the fact that stock options can serve as a mechanism to induce desirable risk taking, increasing stock options will not necessarily exert significant influence on managerial actions because motivational effects of stock options may vary. Cheng (2004) has identified two factors that explain the contemporaneous association between changes in R\&D spending and changes in CEO compensation. In this study, we extend his study by examining additional factors that affect compensation committees' attempt to motivate R\&D spending.

\footnotetext{
${ }^{3}$ Compensation committees are also responsible for executive stock option grants other than those for CEOs.
} 
We argue that three factors will affect the extent to which compensation committees should motivate $R \& D$ spending using stock options. And in situations when compensation committees have more incentives to compensate managerial risk taking, they will establish a stronger positive association between changes in R\&D spending and changes in CEO stock option compensation. In contrast, when compensation committees do not want to motivate managerial risk taking, the link between stock option grants with R\&D spending will be weak. We predict that three factors will affect the compensation committees' incentives to stimulate R\&D spending.

The first factor is a firm's growth opportunities. To what extent compensation committees attempt to motivate R\&D investment is contingent on firms' growth opportunities. CEO stock options are useful when direct monitoring of management is difficult. In firms with more valuable growth opportunities, managers hold considerable private information. Thus, compensation committees have greater difficulty evaluating managers' success in choosing among investments than in firms with fewer growth opportunities. As such, accounting numbers are likely to be less reliable for firms to design earning-based compensation (Watts and Zimmerman 1986). Stock options, in such a situation, will serve as an alternative approach for firms to compensate CEOs. That is to say, in firms with large growth opportunities, compensation committees will grant more stock options to stimulate investments in risky projects, such as R\&D projects. If this argument is valid, we should observe a stronger positive association between changes in $R \& D$ expenditures and changes in CEO stock options for firms in face of more growth opportunities than for firms in face of fewer growth opportunities. Thus, our first hypothesis in an alternative form is:

H1: Ceteris paribus, the positive association between changes in R\&D expenditures and changes in CEO stock option awards increases in the firm's growth opportunities.

Whether compensation committees attempt to motivate more R\&D investment also depends on the firms' financial leverage. For a firm in financial leverage, the cost of debt is high. As argued by John and John (1993), if managers have strong incentives to maximize firm value, debt holders will demand a higher risk premium for supplying capital. Stock options will motivate managers to maximize firm value through pursuing risky investment projects (Sanning 2003). As such, debt-holders may view their interests as threatened and impose higher lending costs on the firm (Whittred et al. 1999; Coulton and Taylor 2002). Due to this concern, compensation committees will not utilize stock options to motivate managers to invest in risky projects. In contrast, when a firm is less financially levered, the compensation committee will feel the need to motivate managers to invest in R\&D projects. Due to the above discussion, our second hypothesis in an alternative form is:

H2: Ceteris paribus, the positive association between changes in R\&D expenditures and changes in CEO stock option awards declines with the firm's financial leverage.

A third factor that affects the relationship between stock option granting decisions and managerial R\&D decisions is the CEO's prior ownership, measured by percentage of stock held at the beginning of a year. Theories have long identified how levels of managerial stock ownership as a symptom of corporate agency problems (e.g., Jensen and Meckling 1976). When CEOs have large stock ownership, their interests are already aligned with those of shareholders (Yermack 1995; Bryan et al. 2000). In this situation, stock options are less effective to influence R\&D spending decisions than when CEOs do not have large stock ownership. If compensation committees take this factor into account, they will be more likely to reinforce the association between R\&D investment and option granting decisions when the CEOs hold relatively few stocks than when the CEOs have relatively large stock ownership. Thus, we develop our third hypothesis in an alternative form as follows:

H3: Ceteris paribus, the positive association between changes in R\&D expenditures and changes in CEO stock option awards is decreasing in CEO prior stock ownership. 


\section{Research Methodology} as follows:

To empirically test our hypotheses, we propose a stock option granting model modified from Cheng (2004)

$\Delta \mathrm{CEO} \_\mathrm{OP}_{i t}=b_{0}+b_{1} \Delta \mathrm{R} \& \mathrm{D}_{i t}+b_{2} \Delta \mathrm{R} \& \mathrm{D}_{i t} \times$ Tobin's $\mathrm{Q}_{i t}+b_{3} \Delta \mathrm{R} \& \mathrm{D}_{i t} \times$ Leverage $_{i t}+b_{4} \Delta \mathrm{R} \& \mathrm{D}_{i t} \times$ Stock_Own $_{i t}+$

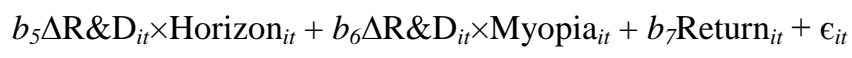

where:

CEO_OP $i t=$ value of CEO annual stock option grants (in millions) of firm $i$ in fiscal year $t$, valued at the end of the fiscal year using Black-Scholes model adjusted for dividends;

$\Delta \mathrm{CEO} \_\mathrm{OP}_{i t}=\mathrm{CEO} \_\mathrm{OP}{ }_{i t}-\mathrm{CEO} \_\mathrm{OP}$ it-1

$\mathrm{R} \& \mathrm{D}_{i t}=\mathrm{R} \& \mathrm{D}$ expenditures of firm $i$ in fiscal year $\mathrm{t}$, scaled by the average book value of common equity;

$\Delta \mathrm{R} \& \mathrm{D}_{i t}=\mathrm{R} \& \mathrm{D}_{i t}-\mathrm{R} \& \mathrm{D}_{i t-1}$

Tobin's $\mathrm{Q}_{i t}=\left(\right.$ book value of total assets $_{i t}+$ market value of common stock $_{i t}-$ book value of common stock $\left._{i t}\right) /$ book value of total assets ; ;

Leverage $_{i t}=$ ratio of total debts to total assets for firm $i$ in year $t$;

Stock_own ${ }_{i t}=$ the percentage of the firm's shares owned by the CEO for firm $i$ in year $t$;

Horizon $_{i t}=1$ if the CEO of firm $i$ in year $t$ is 63 or older, and 0 otherwise;

Myopia $_{i t}=1$ if firm $i$ faces a small earnings decline or a small loss in year $t$, and 0 otherwise, where (i) Firm $i$ in

year $t$ has a "small earnings decline" if (1) pretax income ${ }_{i t}+\mathrm{R} \& \mathrm{D}$ expenditures $_{i t}<$ pretax $_{\text {income }}$ pr- $-1_{1}+\mathrm{R} \& \mathrm{D}$

expenditures $_{i t-1}$, and (2) pretax income ${ }_{i t}+\mathrm{R} \& \mathrm{D}$ expenditures $_{i t}>\operatorname{pretax}_{\text {income }}$ prt- $_{\text {; }}$; (ii) Firm $i$ in year $t$ has a "small

loss" if $-1 \% \leq$ pretax income $_{i t} /$ market value of equity $_{i t-1}<0$;

Return $_{i t}=$ annual stock return of firm $i$ in year $t$.

Cheng's (2004) model captures the link between the contemporary changes in R\&D and the changes in CEO stock options. The author uses annual changes in CEO stock options ( $\triangle \mathrm{CEO}$ _OP) to measure compensation committees' adjustments in annual stock options. The value of CEO stock options is the value of CEO annual stock option grants at the end of the fiscal year estimated by the Black-Scholes model. He uses changes in R\&D spending $(\triangle R \& D)$ as a proxy for CEO actions in $R \& D$ projects. The interaction terms, $\triangle \mathrm{R} \& \mathrm{D} \times$ Horizon and $\triangle \mathrm{R} \& \mathrm{D} \times$ Myopia, are included in his model because he hypothesizes that changes in R\&D spending are more strongly positively associated with changes in CEO stock options in two situations: (1) when the CEO approaches retirement (Horizon problem), and (2) when the firms faces a small earnings decline or a small loss (Myopia problem). He predicts and finds positive signs with the two interaction terms, $\Delta \mathrm{R} \& \mathrm{D} \times$ Horizon and $\Delta \mathrm{R} \& \mathrm{D} \times$ Myopia.

In this paper, we modify Cheng's (2004) model as follows. We first find measures for our three hypothesized variables. Consistent with prior studies (e.g., Yermack 1995), we use Tobin's Q to measure firms' growth opportunities. Tobin's Q is approximated by adding the book value of assets and the difference between the market and book value of common stock, and dividing this total by the book value of assets. Following prior studies, we measure financial leverage (Leverage) as the ratio of firms' total debts to total assets. CEO stock ownership 
(Stock_Own) is measured as the percentage of the firm's shares owned by the CEO. To test for our three hypotheses, we interact these three variables, Tobin's Q, Leverage, and Stock_Own, with changes in R\&D ( $\Delta R \& D)$ and incorporate the three interaction terms $\Delta \mathrm{R} \& \mathrm{D} \times$ Tobin's $\mathrm{Q}, \Delta \mathrm{R} \& \mathrm{D} \times$ Stock_Own, and $\Delta \mathrm{R} \& \mathrm{D} \times$ Leverage in Model (1).

A positive coefficient on $b_{2}$ will support $H 1$, suggesting the changes in $R \& D$ spending are more strongly positively associated with changes in CEO stock options for firms facing more growth opportunities than for firms facing less growth opportunities. Consistent with $\mathrm{H} 2$, we expect to find a negative coefficient on $\mathrm{b}_{3}$, which will indicate that the changes in $\mathrm{R} \& \mathrm{D}$ spending are more strongly positively associated with changes in CEO stock options for firms in lower financial leverage than for firms in greater financial leverage. As hypothesized in H3, we expect to find a negative sign on $b_{4}$, which will suggest that compensation committees make a stronger positive link when the CEOs own a smaller number of firm stocks than when the CEOs own a significant number of firm stocks.

In addition, we add stock performance, measured as annual stock return (Return), in the model because prior studies document that stock performance has a positive effect on CEO stock option grants (e.g., Baber et al. 1996; Cheng 2004). We predict a positive sign on Return.

\section{Sample And Data}

We find an initial sample of all firms in Standard \& Poor's ExecuComp database over the period 1992-2006. The firms included in the database are $S \& P 1500$ (including the $S \& P 500$, the $S \& P$ MidCap 400, and the $S \& P$ SmallCap 600) firms. Prior analytical studies (e.g., Demsetz and Lehn 1985, Smith and Watts 1992) document that in highly regulated industry, managers have little discretion in investment decisions and therefore, executive stock options generate lower incentives. Following Smith and Watts (1992) and Yermack (1995), we identify regulated industries as utility (two-digit SIC code $=49$ ), banking (two-digit SIC code $=60$ or 69), and insurance (two-digit SIC code $=63$ ). The small size of regulated-industry firms in our sample ( 9 firm-year observations) does not allow an adequate empirical investigation on the differential incentives between regulated industries and non-regulated industries. Therefore, we exclude these observations and explore our research hypotheses in a non-regulated industry setting.

Data on Black-Scholes value of stock options awarded to CEO, age of CEO, and the percentage of the firm's shares owned by the CEO are obtained from the ЕхесиСотр 2006 database. From ExесиСотр 2006 database, we also collect financial statement data and market data, including book value of total assets, book value of common stock, pretax income, market value of equity, market value of common stock, and one year total return to shareholders (Return). Data on total debts, which are used to calculate financial leverage (Leverage) and R\&D expenditures are retrieved from Compustat.

We identify the CEOs for sample firms by the variable CEOANN in Execucomp. This variable indicates whether the executive was the CEO for all or most of the indicated fiscal years. We use the Black-Scholes values as the measures of stock options awarded to CEOs in each year. For CEOs receiving multiple stock option grants in certain years, we add the grants in each year together and use this total value of all stock option grants received during the year for each CEO.

Panel A of Table 1 describes our sample selection criteria. The initial sample includes 24,189 firm-year observations representing 1,500 firms. Deleting the highly regulated industries, including utility, insurance and banking, reduces the number of observations to 20,943. Then, we eliminate 11,423 observations which have incomplete data in Execucomp and Compustat. Age of CEO, percentage of common share outstanding owned by $\mathrm{CEO}$ and $\mathrm{R} \& \mathrm{D}$ expenditures are three data items with most missing values. Our final sample has 9,052 firm-year observations, representing 954 firms.

In Panel B, we report the sample distribution by industry based on two-digit SIC code. Two largest industry groups are manufacturing (36.48\%) and wholesale and retail (26.42\%), followed by service (16.88\%) and food and chemical $(16.67 \%)$. This distribution indicates that firms in our final sample are not heavily concentrated in certain industries. Therefore, our conclusions may be generalized to all non-regulated industries. 
Table 1

Sample Selection

Panel A: Sample Selection Procedure

\begin{tabular}{|c|c|c|}
\hline & No. of firms & No. of observations \\
\hline Initial sample & 1,500 & 24,189 \\
\hline $\begin{array}{l}\text { Less: Highly-regulated industries: utility }(\mathrm{SIC}=49) \text {, insu } \\
\text { (SIC }=63) \text {, banking }(\mathrm{SIC}=60,69)\end{array}$ & & 3,246 \\
\hline Less: Missing data in Execucomp and Compustat & & $\begin{array}{l}20,943 \\
11,423 \\
\end{array}$ \\
\hline Final sample size & 954 & 9.052 \\
\hline
\end{tabular}

Panel B: Sample distribution by industry

\begin{tabular}{cccc}
\hline Industry & Two-digit SIC code & No. offirms & \% in sample \\
\hline Mining & $10,13,16$ & 1 & $0.10 \%$ \\
Construction & 15 & 7 & $0.73 \%$ \\
Food and Chemical & $20-29$ & 159 & $16.67 \%$ \\
Manufacturing & $30-39$ & 348 & $36.48 \%$ \\
Transportation & $40,45,48$ & 26 & $2.73 \%$ \\
Wholesale and Retail & $50-59$ & 252 & $26.42 \%$ \\
Service & $70,72,73,75,78-79,80,87$ & 161 & $16.88 \%$ \\
Total & & 954 & $100 \%$ \\
\hline
\end{tabular}

\section{Empirical Results}

Table 2 presents summary statistics for firms across 1992 to 2006. The mean (median) of annual stock options received by CEOs (CEO_OP) is 3.194 (0.934) million. The third quartile is 2.297 million. These statistics suggest that less than twenty-five percent of CEOs in our sample firms receive a significant large amount of stock options than other firms in the sample. The mean (median) of R\&D expenditures (R\&D) is 44.722 (15.899) million. The third quartile is 39.993 million. This indicates that less than twenty-five percent of our sample firms have significantly large R\&D investment. The mean (median) change in the natural log value of CEO stock options ( $\triangle \mathrm{CEO} \_$OP) is $-0.146(-0.124)$ million. The mean (median) change in R\&D expenditures is -0.105 (0) thousand. ${ }^{4}$

The mean (median) Tobin's Q, the measure for growth opportunities, is 2.623 (2.903). On average, CEOs own 3.668 percent of firms' common stock, while most CEO stock owns 3.6 percent. The mean (median) of financial leverage (Leverage), which is measured as the ratio of total debts to total assets, is $43.9 \%$ (58.2\%). In addition, in 12.2 percent of our sample firms, CEOs are at retirement age and 7.5 percent face a small earning decline or a small loss.

Table 3 presents Pearson and Spearman correlations among the variables in Model (1). Pearson (Spearman) correlations are reported in the upper (lower) diagonal. The Pearson correlation between $\triangle \mathrm{CEO} O \mathrm{OP}$ and $\triangle \mathrm{R} \& \mathrm{D} \times$ Tobin's $\mathrm{Q}$ is not significant, while the Spearman correlation is positively significant. $\triangle \mathrm{CEO} O \mathrm{OP}$ and $\triangle \mathrm{R} \& \mathrm{D} \times$ Leverage are not significantly correlated in the Pearson correlation, but significantly negatively correlated in the Spearman correlation. The correlations between $\triangle \mathrm{CEO} \_\mathrm{OP}$ and $\triangle \mathrm{R} \& \mathrm{D} \times$ Stock_Own are significant in both correlations.

\footnotetext{
${ }^{4}$ Model (1) in this paper is modified from Cheng (2004). Following his model specification, we use the thousand dollars of changes in R\&D expenditures.
} 
Table 2

Descriptive statistics of 954 sample firms (9,052 firm-year observations) from 1992 to 2006

\begin{tabular}{|c|c|c|c|c|c|c|c|}
\hline & Mean & $\begin{array}{c}\text { Standard } \\
\text { Deviation }\end{array}$ & Min & 1st quartile & Median & 3rd quartile & $\operatorname{Max}$ \\
\hline CEO_OP (\$ millions) & 3.194 & 14.01 & 0.001 & 0.393 & 0.934 & 2.297 & 369.3 \\
\hline R\&D (\$ thousands) & 44.72 & 106 & 0 & 2.051 & 15.899 & 39.993 & 1642 \\
\hline$\triangle$ CEO_OP (\$ millions) & -0.146 & 1.981 & -7.569 & -1.424 & -0.124 & 1.118 & 9.543 \\
\hline$\Delta \mathbf{R} \& \mathbf{D}(\$$ thousands) & -0.105 & 5.739 & -258.5 & -0.002 & 0 & 0.016 & 20.68 \\
\hline Tobin's Q & 2.623 & 3.047 & 0.495 & 1.282 & 1.802 & 2.903 & 77.64 \\
\hline Leverage & 0.439 & 0.210 & 0.016 & 0.271 & 0.441 & 0.582 & 1.467 \\
\hline Stock_own (in percentage) & 3.668 & 6.274 & 0.002 & 0.42 & 1.265 & 3.6 & 43.93 \\
\hline Horizon & 0.122 & 0.328 & 0 & 0 & 0 & 0 & 1 \\
\hline Myopia & 0.075 & 0.264 & 0 & 0 & 0 & 0 & 1 \\
\hline Return (in percentage) & 26.444 & 97.289 & -97.230 & -20.737 & 10.668 & 45.85 & 1772.6 \\
\hline
\end{tabular}

Variables are defined as follows:

CEO_OPit $=$ value of CEO annual stock option grants (in millions) of firm $i$ in fiscal year $\mathrm{t}$, valued at the end of the fiscal year using Black-Scholes model adjusted for dividends;

$\Delta$ CEO_OP ${ }_{i t}=$ CEO_OP $i t-$ CEO_OP ${ }_{i t-l}$;

$\mathrm{R} \& \mathrm{D}_{i t}=\mathrm{R} \& \mathrm{D}$ expenditures of firm $i$ in fiscal year $t$, scaled by the average book value of common equity;

$\Delta \mathrm{R} \& \mathrm{D}_{i t}=\mathrm{R} \& \mathrm{D}_{i t}-\mathrm{R} \& \mathrm{D}_{i t-1}$

Tobin's $\mathrm{Q}_{i t}=\left(\right.$ book value of total assets ${ }_{i t}+$ market value of common stock ${ }_{i t}-$ book value of common stock $\left._{i t}\right) /$ book value of total assets ${ }_{i t}$;

Stock own ${ }_{i t}=$ the percentage of the firm's shares owned by the CEO for firm $i$ in year $t$

Leverage $_{i t}=$ ratio of total debts to total assets for firm $i$ in year $t$;

Horizon $_{i t}=1$ if the CEO of firm $i$ in year $t$ is 63 or older, and 0 otherwise;

Myopia $_{i t}=1$ if firm $i$ faces a small earnings decline or a small loss in year $t$, and 0 otherwise, where (i) Firm $i$ in year $t$ has a "small earnings decline" if (1) pretax income

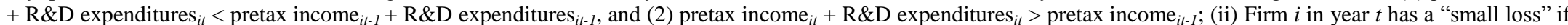

$-1 \% \leq$ pretax $_{\text {income }}{ }_{i t} /$ market value of equity $_{i t-1}<0$;

Return $_{i t}=$ annual stock return of firm $i$ in year $t$. 
Table 3

Pearson and Spearman correlations between variables in Model (1)

\begin{tabular}{|c|c|c|c|c|c|c|c|}
\hline & $\triangle C E O \_O P$ & $\begin{array}{c}\triangle R \& D \times \\
\text { Tobin's } Q\end{array}$ & $\begin{array}{c}\Delta R \& D \times \\
\text { Stock_Own }\end{array}$ & $\begin{array}{c}\Delta R \& D \times \\
\text { Leverage }\end{array}$ & $\begin{array}{l}\Delta R \& D \times \\
\text { Horizon }\end{array}$ & $\begin{array}{l}\triangle R \& D \times \\
\text { Myopia }\end{array}$ & Return \\
\hline$\triangle \triangle$ CEO_OP & & $\begin{array}{c}0.020 \\
(0.368)\end{array}$ & $\begin{array}{c}0.016 \\
(0.046)\end{array}$ & $\begin{array}{l}-0.016 \\
(0.477)\end{array}$ & $\begin{array}{c}-0.004 \\
(0.860)\end{array}$ & $\begin{array}{c}0.013 \\
(0.057)\end{array}$ & $\begin{array}{c}0.029 \\
(0.193)\end{array}$ \\
\hline$\Delta \mathbf{R} \& \mathbf{D} \times$ Tobin's $\mathbf{Q}$ & $\begin{array}{c}0.093 \\
(0.001)\end{array}$ & & $\begin{array}{c}0.268 \\
(0.001)\end{array}$ & $\begin{array}{c}0.295 \\
(0.001)\end{array}$ & $\begin{array}{c}0.061 \\
(0.006)\end{array}$ & $\begin{array}{l}0.0217 \\
(0.327)\end{array}$ & $\begin{array}{l}-0.038 \\
(0.082)\end{array}$ \\
\hline $\begin{array}{c}\Delta \mathbf{R} \& \mathbf{D} \times \text { Stock_O } \\
\text { wn }\end{array}$ & $\begin{array}{c}0.066 \\
(0.003)\end{array}$ & $\begin{array}{c}0.352 \\
(0.001)\end{array}$ & & $\begin{array}{c}0.276 \\
(0.001)\end{array}$ & $\begin{array}{c}0.282 \\
(0.001)\end{array}$ & $\begin{array}{c}0.011 \\
(0.627)\end{array}$ & $\begin{array}{l}-0.043 \\
(0.050)\end{array}$ \\
\hline$\Delta \mathbf{R} \& \mathrm{D} \times$ Leverage & $\begin{array}{l}-0.081 \\
(0.002)\end{array}$ & $\begin{array}{c}0.276 \\
(0.001)\end{array}$ & $\begin{array}{c}0.242 \\
(0.001))\end{array}$ & & $\begin{array}{l}0.0747 \\
(0.008)\end{array}$ & $\begin{array}{c}0.007 \\
(0.767)\end{array}$ & $\begin{array}{l}-0.051 \\
(0.022)\end{array}$ \\
\hline$\Delta \mathbf{R} \& \mathbf{D} \times$ Horizon & $\begin{array}{l}-0.007 \\
(0.742)\end{array}$ & $\begin{array}{c}0.271 \\
(0.001)\end{array}$ & $\begin{array}{c}0.322 \\
(0.001)\end{array}$ & $\begin{array}{c}0.295 \\
(0.001)\end{array}$ & & $\begin{array}{c}0.040 \\
(0.073)\end{array}$ & $\begin{array}{c}0.018 \\
(0.413)\end{array}$ \\
\hline$\Delta \mathbf{R} \& D \times$ Myopia & $\begin{array}{l}0.026 \\
(0.25)\end{array}$ & $\begin{array}{c}0.317 \\
(0.001)\end{array}$ & $\begin{array}{c}0.310 \\
(0.001)\end{array}$ & $\begin{array}{c}0.307 \\
(0.001)\end{array}$ & $\begin{array}{c}0.060 \\
(0.007)\end{array}$ & & $\begin{array}{c}0.041 \\
(0.067)\end{array}$ \\
\hline Return & $\begin{array}{c}0.073 \\
(0.001)\end{array}$ & $\begin{array}{c}0.209 \\
(0.001)\end{array}$ & $\begin{array}{c}0.191 \\
(0.001)\end{array}$ & $\begin{array}{c}0.190 \\
(0.001)\end{array}$ & $\begin{array}{c}0.022 \\
(0.312)\end{array}$ & $\begin{array}{c}0.061 \\
(0.006)\end{array}$ & \\
\hline
\end{tabular}

Pearson correlation coefficients are reported above the diagonal and Spearman correlation coefficients below.

p-values (two-tailed) are reported in parentheses.

Variables are defined in Table 2. 
Table 4 presents the regression results of Model (1). Pooled regression results are reported. ${ }^{5}$ The model explains 9.38 percent of variation in CEO stock option adjustments (Adjusted $\mathrm{R}^{2}=9.38 \%$ ). The insignificance of $\triangle R \& D$ is consistent with Matsunaga (1995), Yermack (1995) and Cheng (2004) who all find that R\&D intensity is not associated with the value of employee stock options or the sensitivity of the value of CEO stock options to performance.

H1 predicts that the contemporaneous positive association between changes in R\&D expenditures and changes in CEO stock options is more pronounced when the firm faces more valuable growth opportunities. The coefficient on $\Delta \mathrm{R} \& \mathrm{D} \times$ Tobin' $\mathrm{Q}\left(b_{2}\right)$ is 0.060 with the White-adjusted t-statistic of 2.12 (significant at the 0.05 level), which supports H1. This is consistent with the notion that compensation committees are more likely to use stock options to motivate R\&D spending when they observe a strong growth potential of the firms.

$\mathrm{H} 2$ predicts that the contemporaneous positive association between changes in $\mathrm{R} \& \mathrm{D}$ expenditures and changes in CEO stock options is stronger when the firm's financial leverage is lower. The coefficient on $\Delta \mathrm{R} \& \mathrm{D} \times$ Leverage $\left(b_{3}\right)$ is -0.358 . The White-adjusted t-statistic is -3.24 and is significant at the 0.01 level. This result supports $\mathrm{H} 2$, suggesting that compensation committees are more likely to use stock options to motivate R\&D spending when the cost of debt is not high.

The coefficient on $\Delta \mathrm{R} \& \mathrm{D} \times$ Stock_Own is significantly positive $\left(b_{4}=0.143\right.$, White-adjusted $\mathrm{t}$-statistic $=$ 1.99). This finding suggests that the positive association between changes in R\&D expenditures and changes in CEO stock options is more pronounced when the CEO has larger stock ownership than when the CEO has smaller stock ownership. In other words, compensation committees tend to grant more to CEOs with significant stock ownership.

One potential explanation for this granting behavior is that CEOs affect compensation decisions when they own a large portion of firm stocks. This is more likely to happen when CEOs serve as directors in the boards. This evidence corroborates Core et al. (1999), who find that CEOs who are also chairmen of the boards in the 1982-1984 period were paid more than other CEOs. In line with their finding, Hermalin and Weisbach (2001) argue that the greatest factor ensuring the effectiveness of board of directors is its independence from the CEO. Therefore, the evidence suggests that the independence of boards of directors appears a key factor in the effectiveness of stock option granting decisions.

In addition to the results of the three hypothesized variables, consistent with prior research (e.g., Barber et al. 1991; Cheng 2004), annual stock return (Return) is positively associated with changes in CEO stock options $\left(\mathrm{b}_{7}=\right.$ 0.001, White-adjusted t-statistic $=3.47$ ). Our findings with the two variables proposed in Cheng (2004), $\Delta \mathrm{R} \& \mathrm{D} \times$ Horizon and $\Delta \mathrm{R} \& \mathrm{D} \times$ Myopia, are as follows. As reported in Table 5, the coefficient on $\triangle \mathrm{R} \& \mathrm{D} \times$ Horizon is significantly negative $\left(b_{5}=0.648\right.$, White-adjusted t-statistic $\left.=1.93\right)$. Consistent with Cheng $(2004)$, this result suggests that compensation committees issue more stock options to CEOs based on the increasing R\&D investment when the CEO approaches retirement. However, the coefficient on $\triangle \mathrm{R} \& \mathrm{D} \times$ Myopia $\left(b_{6}\right)$ is not significant at conventional levels, indicating that compensation committees do not address the CEOs' short-term earnings concerns in their stock option decision making.

The possible reason for the insignificant result of $\Delta \mathrm{R} \& \mathrm{D} \times$ Myopia may be that our sample differs from Cheng (2004). Cheng's (2004) sample period is from 1984 to 1997, and our sample covers the period of 1992-2006. The granting pattern of compensation committees might change with time. Furthermore, Cheng (2004) uses 160 R\&D-intensive firms in Forbes 500 list, while we select a sample of 954 firms from the Standard \& Poor's 1500. Therefore, his results merely apply to R\&D-intensive firms. And the findings in this study have implications for both $R \& D$ intensive firms and non-R\&D-intensive firms.

Overall, the findings in Table 4 suggest that firms with greater growth opportunities and firms with lower financial leverage are more likely to award CEO stock options to motivate R\&D investment. However, contrary to our prediction, compensation committees tend to grant more to CEOs with significant stock ownership to induce R\&D spending. A potential explanation for this finding is that CEOs with significant stock ownership affect the contracting process and grant themselves with more options.

\footnotetext{
${ }^{5}$ We also use the fixed effect model by adding year dummy variables. The results (untabulated) are qualitatively unchanged.
} 
Table 4

Regression results of Model (1)

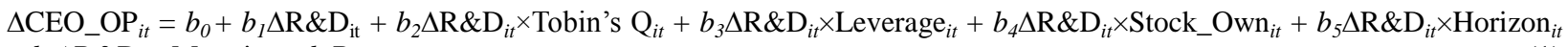
$+b_{6} \Delta \mathrm{R} \& \mathrm{D}_{i t} \times \mathrm{Myopia}_{i t}+b_{7} \operatorname{Return}_{i t}+\epsilon_{i t}$

\begin{tabular}{|c|c|c|c|}
\hline \multicolumn{4}{|c|}{ Predicted sign } \\
\hline & & Coefficient estimate & While-adjusted t-statistic \\
\hline Intercept & $?$ & $-0.161^{* * *}$ & -5.89 \\
\hline$\Delta \mathrm{R} \& \mathrm{D}$ & + & 0.921 & 0.93 \\
\hline$\Delta \mathrm{R} \& \mathrm{D} \times$ Tobin' $\mathrm{Q}$ & + & $0.060^{* * *}$ & 2.12 \\
\hline$\Delta \mathrm{R} \& \mathrm{D} \times$ Leverage & - & $-0.358^{* * *}$ & -3.24 \\
\hline$\Delta \mathrm{R} \& \mathrm{D} \times$ Stock_Own & - & $0.143^{* *}$ & 1.99 \\
\hline$\Delta \mathrm{R} \& \mathrm{D} \times$ Horizon & + & $0.648^{* * *}$ & 1.93 \\
\hline$\Delta \mathrm{R} \& \mathrm{D} \times$ Myopia & + & 0.022 & 0.31 \\
\hline \multirow{2}{*}{\multicolumn{2}{|c|}{ Adj. $\mathbf{R}^{2}$}} & $0.001^{* * * *}$ & 3.47 \\
\hline & & & $9.38 \%$ \\
\hline
\end{tabular}

, otherwise.

Variables are defined in Table 2.

\section{Concluding Remarks}

This paper examines compensation committees' strategies of using stock options to motivate R\&D investments. The findings suggest that firms do consider their investment and financing conditions when they make decisions in stock option grants. Specifically, when firms face greater growth opportunities and when firms are less financially levered, compensation committees are more likely to intensify the association between their CEO stock option granting decisions and CEOs' decisions on R\&D investment. These findings are consistent with that options are designed effectively to motivate managerial risk taking, thereby aligning the interests of managers with those of shareholders. However, contrary to our prediction, compensation committees tend to grant more stock options to reward or motivate $\mathrm{R} \& \mathrm{D}$ spending when the CEOs hold large stock ownership. One potential explanation for this granting behavior is that CEOs affect compensation decisions when they own a large portion of firm stocks.

Several potential opportunities for future research arise from this study. First, the empirical evidence provided in this paper may suggest that CEOs with significant stock ownership affects the option granting process. Future empirical research might seek supporting evidence on this conjecture. Second, future research could also provide insights on whether and how board of director independence affects the effectiveness of stock option grants. Third, due to data limitations, we do not address the granting patterns in regulated industries. Future studies might investigate stock option grants practice in such industries.

Data Availability: Data used in this study are publicly available from the sources identified in the paper.

\section{References}

1. Barber, W., P. Fairfield, and J. Haggard. 1991. The effect of concern about reported income on discretionary spending decisions: The case of research and development. The Accounting Review 66 (October): 818-829.

2. Bertrand, M., and M. Sendhil. 2000. Do CEOs set their own pay? The ones without principals do. Working Paper. MIT.

3. Bryan, S., and L. Hwang. 2000. CEO stock-based compensation: An empirical analysis of incentive-intensity, relative mix, and economic determinants. Journal of Business 73 (October): 661-693.

4. Chan, L., J. Lakonishok, and T. Sougiannis. 2001. The stock market valuation of research and development expenditures. Journal of Finance 56 (December): 2431-2456.

5. Cheng, S. 2004. R\&D expenditures and CEO compensation. The Accounting Review 79 (April): 305-328. 
6. Clinch, G. 1991. Employee compensation and firms' research and development activity. Journal of Accounting Research 29 (Spring): 58-79.

7. Coulton J., and S. Taylor. 2002. Option awards for Australian CEOs: Who, what and why. Australian Accounting Review 12 (1): 25-35.

8. Dechow, P., M. Huston, and R. Sloan. 1994. The effect of restructuring charges on executives' cash compensation. The Accounting Review 69 (January): 138-156.

9. Duru, A., R. Iyengar, and A. Thevaranjan. 2002. The shielding of CEO compensation from the effects of strategic expenditures. Contemporary Accounting Research 19 (Summer): 175-193.

10. Gaver, J., and K. Gaver. 1998. The relation between nonrecurring accounting transactions and CEO cash compensation. The Accounting Review 73 (April): 235-254.

11. Goodwin, J., and P. Kent. 2004. The incentives of Australian companies to utilize executive stock option plans. Corporate Ownership \& Control 1 (Winter): 137-149.

12. Hall, B., and K. Murphy. 2002. Optimal exercise prices for executive stock options. American Economic Review 90 (May): 209-214.

13. Hanlon, M., S. Rajgopal and T. Shevlin. 2003. Are executive stock options associated with future earnings? Journal of Accounting and Economics 36 (October): 3-43.

14. Hermalin, B., and M. Weisbach. 2001. Boards of directors as an endogenously determined institution: a survey of the economic literature. Working paper, University of California, Berkeley.

15. Ikaheimo, S., A. Kjellman, J. Holmberg, and S. Jussila. 2004. Employee stock option plans and stock market reaction: Evidence from Finland. European Journal of Finance 10 (April): 105-122.

16. Jensen, M., and W. Meckling. 1976. Theory of the firm: Managerial behavior agency costs, and ownership structure. Journal of Financial Economics 3 (October): 305-360.

17. Jenter, D. 2001. Understanding High-Powered Incentives. Working paper, Harvard University.

18. John, T., and K. John. 1993. Top-management compensation and capital structure. The Journal of Finance 48 (July): 949-974.

19. Kothari, S., T. Laguerre, and A. Leone. 2002. Capitalization versus expensing: Evidence on the uncertainty of future earnings from capital expenditures versus R\&D outlays. Review of Accounting Studies 7 (December): 355-382.

20. Kren L., and B. Leauby. 1997. The effect of SFAS No. 106 on chief executive compensation. Working paper, University of Wisconsin-Milwaukee.

21. Leonhardt, D. 2000. Report on executive pay: Orders of compensation universe reflects pull of new economy. New York Times (April 2).

22. Matsunaga, S. 1995. The effects of financial reporting costs on the use of employee stock options. The Accounting Review 70 (January): 1-26.

23. Meulbroek, L. 2003. The efficiency of equity-linked compensation: Understanding the full cost of awarding executive stock options. Working paper, Harvard Business School.

24. Morgenson, G. 1998. Stock options are not a free lunch. Forbes (May 18): 212-217.

25. Murphy, K. 2003. Stock-based pay in new economy firms. Journal of Accounting and Economics 34(January): 129-147.

26. Rajgopal, S., and T. Shevlin. 2002. Empirical evidence on the relation between stock option compensation and risk taking. Journal of Accounting and Economics 33 (June): 145-171.

27. Sanning, L. 2003. Executive stock options and leverage: Perverse incentives or optimal contracting, a test of causality. Working paper. University of Wyoming.

28. Smith, C., and R. Watts. 1992. The investment opportunity set and corporate financing, dividend, and compensation policies. Journal of Financial Economics 32 (December): 263-292.

29. Tian, Y. 2004. Too much of a good incentive? The case of executive stock options. Journal of Banking \& Finance 28 (June): 1225-1245.

30. Watts, R., and J. Zimmerman. 1986. Positive Accounting Theory Prentice Hall, Englewood Cliffs, NJ.

31. Whittred, G., I. Zimmer, and S. Taylor. 1999. Financial Accounting: Incentive Effects and Economic Consequences. $5^{\text {th }}$ edition (Harcourt Brace, Sydney)

32. Yermack, D. 1995. Do corporations award CEO stock options effectively? Journal of Financial Economics 39 (October/November): 237-269. 
NOTES 